UDC 614.715: 614.78: [625.739.4+625.734.2]

DOI: 10.21668/health.risk/2016.4.05.eng

\title{
INVESTIGATIONS OF FINE PARTICLES CONCENTRATIONS IN THE ATMOSPHERIC AIR NEAR HIGHWAYS
}

\author{
T.S. Ulanova ${ }^{1,2}$, M.V. Antipieva ${ }^{1,3}$, M.V. Volkova ${ }^{1,2}$, M.I. Gileva ${ }^{1}$ \\ ${ }^{1}$ Federal Scientific Center for Medical and Preventive Health Risk Management Technologies, \\ 82 Monastyrskaya Str., Perm, 614045, Russian Federation \\ ${ }^{2}$ Perm National Research Polytechnic University, 29 Komsomolskiy Ave., Perm, 614990, Russian Federation \\ ${ }^{3}$ Perm State Agricultural Academy named after D.N. Pryanishnikova, 23 Petropavlovskaya Str., \\ Perm, 614045, Russian Federation
}

This paper presents the results of the experimental determination of particulate matter $P M_{2,5}, P M_{10}$ mass concentration and total suspended particles up to 15 microns (TSP), which are the priority components of air pollutants near the highways. The measurements were made during the year 2016 using a laser analyzer of aerosol DustTrak 8533. The study shows the dependence of the particulate matter concentration from the time of day and the traffic congestion. The sampling $(N=67)$ was performed due to brief program on the basis of the route monitoring station, which is located on the road junction with heavy traffic - up tol,200 vehicles per hour on the test sites. The single concentrations of the suspended substances reached the levels of the Maximum permissible concentration (MPC) of 1.5. During the study period, the exceeding of the established average daily $M P C$ for fine particles $P M_{2.5}$ and $P M_{10}$ fractions near the highways have not been identified.

The significant linear relationship between the number of diesel vehicles on stops and the concentrations of particulate matter PM $M_{2.5}, P M_{10}$, TSP (correlation coefficient from 0.62 to 0.65 ; Fisher's criterion of 14.2 to $38.0 ; p$ $<0.05)$ has been established and parameterized, what allows to predict the level of air pollution by diesel vehicles when braking and accelerating.

It is recommended to fulfill continuous monitoring of the average daily and single MPC of the fine suspended particles near the roads with traffic load of $769-1270$ or more the diesel vehicles per every 20 minutes. The obtained data may be used in evaluation of the risk to public health induced by the transport emissions as well as in the estimation of the fine particles $P M_{2.5}, P M_{10}$ concentrations on the sites close to the highways of the large industrial center.

Key words: fine particles, $P M_{2,5}, P M_{10}$, transport emissions, atmospheric air, laser nephelometry, correlation coefficient, Fisher's criterion.

Concentrations follow-up control and decrease in air pollution with fine suspended particles PM2.5 and PM10 in large industrial cities is an urgent task of social-hygienic monitoring and human health risk management.

PM2.5 are suspended particles (solids) contained in the air, of aerodynamic diameter less than 2.5 microns, PM10 - of less than 10 microns in diameter. The fine particles pose threat to human health as they penetrate into lungs, causing a number of diseases or aggravating the existing ones [3.23]. According to scientific literature, the concentration of

(C) Ulanova T.S., Antipieva M.V., Volkova M.V., Gileva M.I., 2016

Tatyana S. Ulanova - PhD, DSc, Head of Department of Analytical Chemistry Analysis, Professor of the Department of Environmental Protection (e-mail: ulanova@fcrisk.ru; tel.: +7 (342) 233-10-37).

Marina V. Antipieva - PhD, Senior Researcher, Laboratory of methods of analysis of nanomaterials and fine particles, an assistant professor of botany, genetics, plant physiology and biotechnology (e-mail: girmar@mail.ru; tel.: +7 (342) 233-10-37).

Marina V. Volkova - Chemist of the laboratory for analysis methods of nanomaterials and fine particles, Master of the Department of Environmental Protection (e-mail: volkova@ fcrisk.ru; tel.: +7 (342) 233-10-37).

Marina I. Gileva - Research Engineer of the laboratory for analysis methods of nanomaterials and fine particles (e-mail: gileva@fcrisk.ru; tel.: +7 (342) 233-10-37). 
PM2,5 fraction fine particles affects people mortality and cardiovascular disease occurrence [25].

Standards of fine particles content in the air are set in the official documents of the World Health Organization (WHO) and the European Union [12,24,26]. In the Russian Federation, the content of PM2,5 and PM10 fractions fine particles is subject to standardization since 2010. The daily-average maximum permissible concentration (MPC) is $0.035 \mathrm{mg} / \mathrm{m} 3$ (PM2,5) and $0.06 \mathrm{mg} / \mathrm{m} 3$ (PM10); single maximum $0.16 \mathrm{mg} / \mathrm{m} 3$ and $0.3 \mathrm{mg} / \mathrm{m} 3$; mean year: $0.025 \mathrm{mg} / \mathrm{m} 3$ and $0.04 \mathrm{mg} / \mathrm{m} 3$, respectively [7]. Follow-up control over the environment pollution with suspended particles is of high demand, however, until 2016, determining fine dust concentrations was of scientific research nature only $[4-6,8,13,14,18,22]$, except for the automated monitoring arranged in Moscow, St. Petersburg, Sochi, Kazan [16, 17].

With Ruling document 52.04.830-2015 "Mass concentration of PM10 and PM2.5 suspended particles in the ambient air" and RD1 52.04.840-2015 "Application of the air quality monitoring data obtained using continuous measurement methods" in force since March 2016, the reference gravimetric measurement procedure relating to mass concentration of suspended particles of less than 10 microns and less than 2.5 microns is set, which allows also to determine the correction factor for automatic analyzer.

The peculiarity of the Russian standardization system is a 20-minute data smoothing, including those obtained by means of continuous measurements methods [20]. Direct measurements methods with gas analyzers and dust meters allow for the data-fund on urban air pollution in place. [20]

Under conditions of a large industrial center, fine particles mainly come from anthropogenic sources: vehicle emissions and industry [1]. For example, in Beijing, according to estimates of Beijing Environment protection and monitoring center, PM2.5 particles are generated mainly of coal combustion and exhaust emissions [2].
A large number of fine particles appear in the process of fuel combustion and vehicle diesel-engines operation [9]. Apart from direct emission from engines, fine particles are formed as a result of roadways and tires wear. Soot fine particles, due to their small size, causing a slow natural excretion from the atmosphere, and sorption properties, can increase toxicity by absorption of harmful substances from emissions, being transported to thousands of kilometers, posing threat to human health and environment [9]. The proportion of vehicle emissions in the large cities' air pollution can reach up to $60-90 \%$ [10]. Vehicle emissions contain dozens of different toxic substances, among which fine particles PM2.5, PM10 are a priority, along with benzo(a)pyrene and carbon black [1.14, 15.18].

The present study was aimed at investigating the content of fine particles PM2.5, PM10 in the atmospheric air at close range of auto-roads.

Materials and methods. To determine fine particles content in the air, we used dust analyzer DustTrak, model 8533, with particles size range detected of 0.1 - 15 microns. Measuring aerosol particles mass concentration ranged within $0.01-150 \mathrm{mg} / \mathrm{m} 3$. [21]. Instrumental studies of fine particles and TSP content in the ambient air took place during warm season (spring - summer) in 2016. Measurements were held by the reduced monitoring program in accordance with GOST 17.2.3.01-86 on route station site, located in the areas adjacent to asphalt highways of heavy traffic: 1,200 vehicles per hour on the test areas [11]. Measurement duration and averaging period in determining single concentrations were 20 minutes, unit values were recorded per second. The device was placed at a height of $1.5 \mathrm{~m}$. Measurements went along with air temperature and wind speed follow-up.

Measuring air pollution level caused by vehicle emissions [19] was carried out at different weather conditions and traffic rates. According to regulations [19], the monitoring points were selected in heavy traffic localities in the areas of frequent application of brakes, 
i.e. at highways crossroads and stopping points. The passing vehicles were counted per aerosol concentrations measurements period (20 min). Vehicles were divided into two categories: petrol: cars, motorcycles; diesel: buses and cargo-trucks. In addition, they assessed air pollution with fine particles PM2.5 and PM10 at stops, where people spend a relatively short time, but supposed to be receiving a relatively high dose of fine particles.

The obtained data were compared with the maximum values of single MPC of suspended particles PM2.5 and PM10 in the populated areas atmosphere [7] (Tables 1, 2). Statistical data processing included calculation and estimation of Fisher's criterion, correlation coefficient, taking into account the significance level of $<0.05$.

Results and discussion. Measuring the level of pollution in the ambient air at stopping points showed that under continuous every-second measurements, including measurements during buses' deceleration, stopping and acceleration, the single concentrations of suspended particles are increasing up to $1.5 \mathrm{MPCSM}$. However, by smoothing data obtained for 20-minute interval, no MPCSM exceedence was found (Table 1, Figure 1, 2).

Linear relationship equation $\mathrm{y}=0.0002 \mathrm{x}+0.0062$ is characterized by a correlation coefficient of 0.6452 ; Fisher's criterion was $38.2, \mathrm{p}<0.05$, that confirms the hypothesis on a heavy contribution of diesel vehicles emissions into air pollution with fine particles.

In the process of experimental studies for the stopping point №2, far from traffic lights, in a circular movement, we obtained the dependences of suspended particles PM2.5 and PM10 mass concentrations (y), as well as of TSP, on the number of diesel engine vehicles (x) (Fig.

2).

Measurements data of PM2.5 and PM10 fine particles single maximum concentrations, as well as total dust of up to 15 microns (TSP) at stops

\begin{tabular}{|c|c|c|c|c|c|}
\hline \multirow{4}{*}{$\begin{array}{c}\text { Point of Measure- } \\
\text { ment }\end{array}$} & \multicolumn{2}{|c|}{$\begin{array}{c}\text { Traffic load, vehicles } \\
\text { units } / 20 \mathrm{~min} .\end{array}$} & \multirow{2}{*}{$\begin{array}{c}\mathrm{PM}_{2,5}, \pm \Delta, \mathrm{mg} / \mathrm{m}^{3} \\
\text { Single Max Concen- } \\
\text { tration }\end{array}$} & \multirow{2}{*}{$\begin{array}{l}\mathrm{PM}_{10}, \pm \Delta, \mathrm{mg} / \mathrm{m}^{3} \\
\text { Single Max Con- } \\
\quad \text { centration }\end{array}$} & \multirow{2}{*}{$\begin{array}{l}\mathrm{TSP}, \pm \Delta, \mathrm{mg} / \mathrm{m}^{3} \\
\text { Single Max Con- } \\
\text { centration }\end{array}$} \\
\hline & \multirow{3}{*}{$\begin{array}{l}\text { Diesel } \\
\text { engine }\end{array}$} & \multirow{3}{*}{$\begin{array}{l}\text { Petrol } \\
\text { engine }\end{array}$} & & & \\
\hline & & & \multicolumn{3}{|c|}{ MPC single $\max$ value, $\mathrm{mg} / \mathrm{m}^{3}$} \\
\hline & & & 0,160 & 0,300 & - \\
\hline Bus stop № $1, n=4$ & 95 & 836 & $0,025 \pm 0,005$ & $0,063 \pm 0,013$ & $0,111 \pm 0,022$ \\
\hline Bus stop № $2, n=11$ & 195 & 822 & $0,055 \pm 0,011$ & $0,073 \pm 0,015$ & $0,091 \pm 0,018$ \\
\hline Bus stop № 3, $n=2$ & 80 & 520 & $0,014 \pm 0,003$ & $0,041 \pm 0,008$ & $0,079 \pm 0,016$ \\
\hline Bus stop № $4, n=2$ & 160 & 1400 & $0,027 \pm 0,005$ & $0,038 \pm 0,008$ & $0,039 \pm 0,008$ \\
\hline Bus stop № $5, n=2$ & 120 & 720 & $0,014 \pm 0,003$ & $0,030 \pm 0,006$ & $0,047 \pm 0,009$ \\
\hline Bus stop № $6, n=2$ & 40 & 480 & $0,016 \pm 0,003$ & $0,053 \pm 0,011$ & $0,095 \pm 0,019$ \\
\hline
\end{tabular}

Table 2

Measurements data of $\mathrm{PM}_{2.5}$ and $\mathrm{PM}_{10}$ fine particles single maximum concentrations, as well as total dust of up to 15 microns (TSP) at stops

\begin{tabular}{|c|c|c|c|c|c|}
\hline \multirow{4}{*}{ Point of Measurement } & \multicolumn{2}{|c|}{$\begin{array}{c}\text { Traffic load, vehicles } \\
\text { units } / 20 \mathrm{~min} .\end{array}$} & \multirow{2}{*}{$\begin{array}{l}\text { Single Max Concentra- } \\
\text { tion, } \mathrm{PM}_{2,5}, \pm \Delta, \mathrm{mg} / \mathrm{m}^{3}\end{array}$} & \multirow{2}{*}{$\begin{array}{c}\text { Single Max Concen- } \\
\text { tration, } \mathrm{PM}_{10}, \pm \Delta \\
\mathrm{mg} / \mathrm{m}^{3}\end{array}$} & \multirow{2}{*}{$\begin{array}{c}\text { Single Max Concen- } \\
\text { tration, TSP }, \pm \Delta \\
\mathrm{mg} / \mathrm{m}^{3}\end{array}$} \\
\hline & \multirow{3}{*}{$\begin{array}{l}\text { Diesel } \\
\text { engine }\end{array}$} & \multirow{3}{*}{$\begin{array}{l}\text { Petrol } \\
\text { engine }\end{array}$} & & & \\
\hline & & & \multicolumn{3}{|c|}{ MPC single max value, $\mathrm{mg} / \mathrm{m}^{3}$} \\
\hline & & & 0,160 & 0,300 & 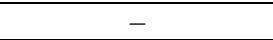 \\
\hline Crossroad № $1, n=30$ & 120 & 1039 & $0,050 \pm 0,010$ & $0,063 \pm 0,013$ & $0,080 \pm 0,016$ \\
\hline Crossroad № 2, $n=4$ & 450 & 3185 & $0,031 \pm 0,006$ & $0,040 \pm 0,008$ & $0,051 \pm 0,010$ \\
\hline Crossroad № 3, $n=4$ & 277 & 1250 & $0,024 \pm 0,005$ & $0,028 \pm 0,006$ & $0,040 \pm 0,008$ \\
\hline Crossroad № 4, $n=2$ & 160 & 1000 & $0,051 \pm 0,010$ & $0,093 \pm 0,019$ & $0,100 \pm 0,020$ \\
\hline Crossroad № 5, $n=2$ & 100 & 1080 & $0,011 \pm 0,002$ & $0,020 \pm 0,004$ & $0,034 \pm 0,007$ \\
\hline
\end{tabular}




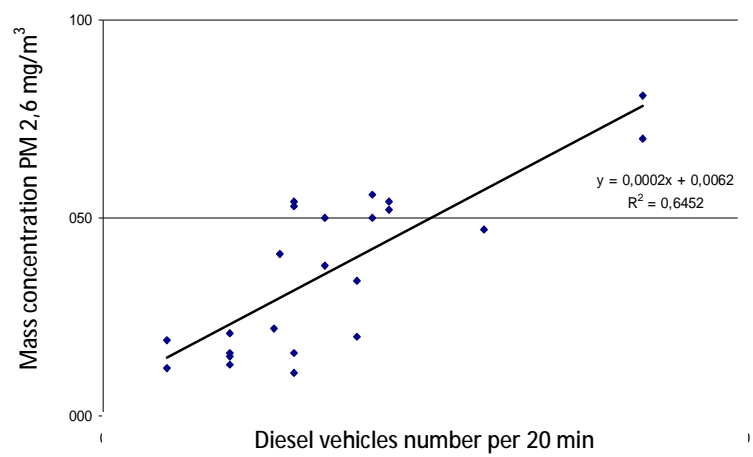

Fig.1. Dependence of single maximum concentration of PM2.5 particles at stopping points on the number of diesel engines vehicles driven along the asphalt road. $\mathrm{N}=23, \mathrm{~F}=38.2, \mathrm{p}<0.05$

Reliability of approximation and adequacy of linear dependence is confirmed with the calculated values of the correlation coefficient and Fisher's criterion: for PM2.5 $\mathrm{y}=0.0001 \mathrm{x}+0.0329 \quad(\mathrm{R} 2=0.6192, \quad \mathrm{~F}=14.6$, $\mathrm{p}<0.05), \quad$ for $\mathrm{PM} 10 \mathrm{y}=0.0001 \mathrm{x}+0.0445$ (R2=0.6196, $\quad \mathrm{F}=14.7, \quad \mathrm{p}<0.05)$, $y=0.0002 x+0.051$, for TSP $(R 2=0.6203$, $\mathrm{F}=14.7, \mathrm{p}<0.05)$. In this case, increasing the concentration of particles in the atmosphere is linearly related to increasing the proportion of particles in the exhaust gases in con-

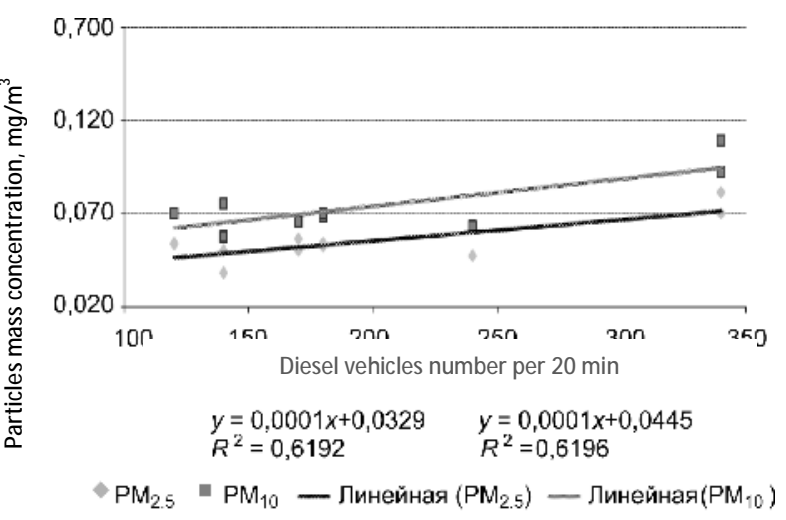

Fig.2. Dependence of single maximum concentration of $\mathrm{PM}_{2.5}$ and $\mathrm{PM}_{10}$ particles at stopping point № 2 on the number of diesel engines vehicles driven along the asphalt road. $\mathrm{N}=11, \mathrm{~F}=14.6, \mathrm{p}<0.05$

ditions of braking and acceleration, and the background level of fine particles concentrations, is likely formed by exhaust gases of vehicles driven at a constant speed, and secondary dust collection from the surface. As for the other stopping points, they were near to traffic lights, so, there were braking factors, vehicles stopping and acceleration, and emissions at idling in the morning and evening traffic jams lined up herewith (Figure 3 ).

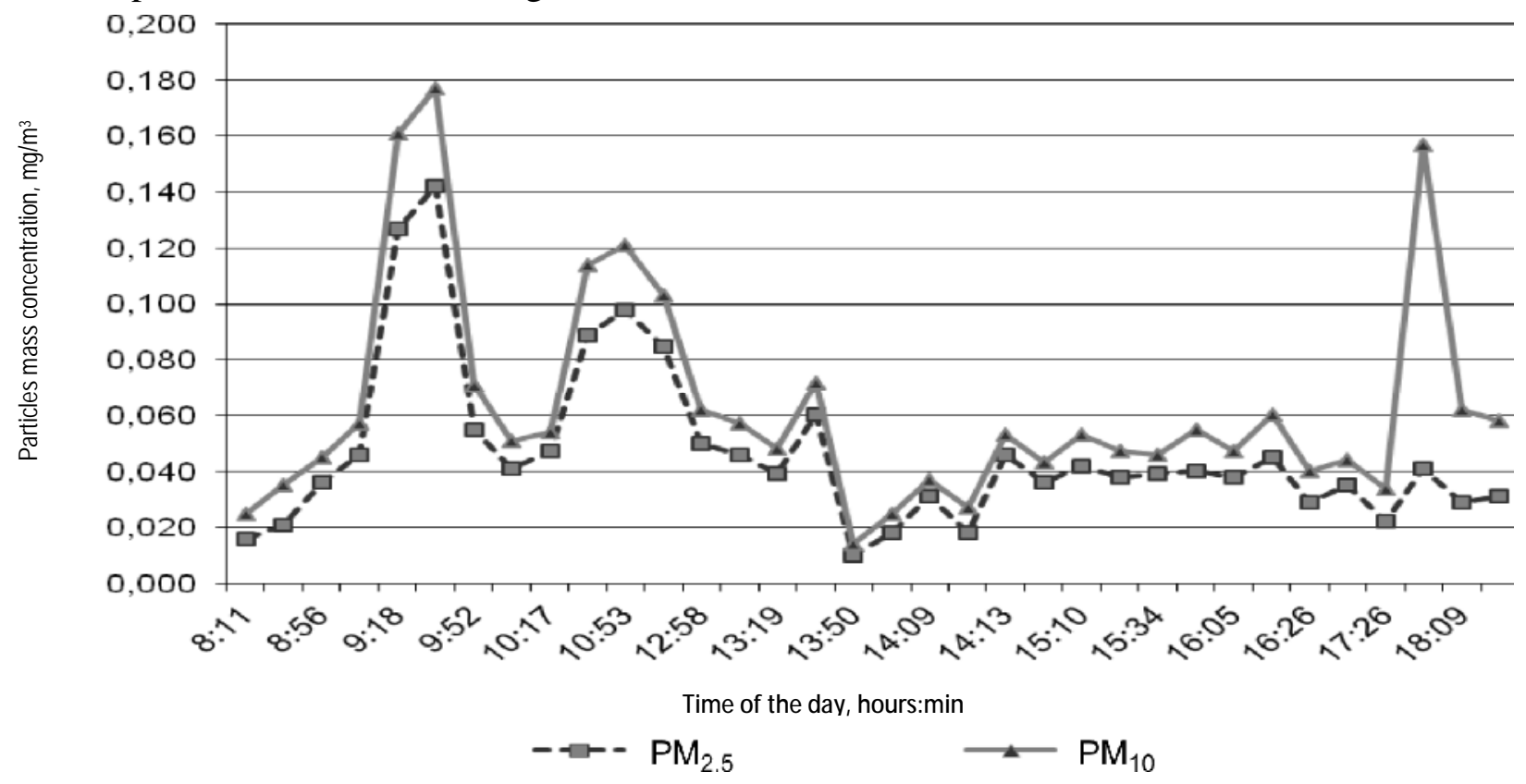

Fig. 3. Dependence of single maximum concentration of $\mathrm{PM}_{2.5}$ and $\mathrm{PM}_{10}$ particles on time of the day 
As per equations obtained, predicting the situation, we can assume that achieving and further exceedence of MACs.max (PM2.5) may occur at a highway stop-point loaded with diesel vehicles, the number of which within 20 minutes must exceed 770 units near the traffic lights or 1271 units far from the traffic lights. In this regard, suspended fine particles single maximum concentrations are rational to be monitored continuously near the roads with traffic close to the reported one.

The measurements results for single maximum concentrations at highways crossroads are given in Table. 2. The measured values of PM2.5 and PM10 fine particles concentrations did not exceed MACs.max. In addition, when determining single maximum concentration of fine particles at crossroads, there was no reliable dependence on the number of vehicles fixed.

Conclusions. When studying fine particles on Perm highways with the traffic intensity of up to 2.5 thousand cars per hour, sus- pended particles mass concentrations averaged over a 20-minute period at stops and crossroads did not exceed the established hygienic standards.

Linear dependencies between the number of diesel vehicles at stops and PM2.5, PM10, TSP suspended particles concentrations have been established and parameterized, which allows predicting the level of atmospheric pollution by diesel vehicles during their braking and acceleration.

It is recommended to continuously monitor daily average suspended fine particles concentrations near big highways, as well as single maximum concentrations of suspended fine particles near roads with diesel vehicles traffic of 769 - 1270 units or more per 20 minutes.

The studies done can be used for calculation of risks for population health due to vehicles emissions and objective assessment of PM2.5 and PM10 fine particles content near the highways of a large industrial center.

\section{References}

1. Alikina E.N., Teplouhova N.V., Ulanov A.V. Opredelenie frakcionnogo sostava i kolichestvennogo soderzhanija melkodispersnyh chastic $\mathrm{v}$ vyhlopah dizel'nyh avtomobilej [Determination of the fractional composition and quantitative content of fine particles in the exhaust of diesel vehicles]. Fundamental'nye i prikladnye aspekty analiza riska zdorov'ju naselenija: materialy Vseross. nauchno-prakt. konf. molodyh uchenyh i specialistov Rospotrebnadzora s mezhdunarodnym uchastiem [Materials of the all-Russian scientific and practical conference of young scientists and Rospotrebnadzor specialists "Fundamental and applied aspects of population health risk"]. 2012, May 16-18, vol. 1, pp. 22-25 (in Russian).

2. V 2015 godu srednjaja koncentracija vzveshennyh chastic RM2,5 v vozduhe v Pekine snizilas' na 6,2 proc. [In 2015, the average concentration of suspended particles $\mathrm{PM}_{2.5}$ in the air in Beijing declined by 6.2 percent.]. Russian news.CN. Available at: http: //russian.news.cn/201601/05/c_134978768.htm (18.11.2016) (in Russian).

3. Vozdejstvie dispersnogo veshhestva na zdorov'e cheloveka [Effects of particulate matter on human health]. Effects of particulate matter on human health. Note by the World Health Organization, Geneva, 2012, 13 p. Available at: http: //www.unece.org: 8080/fileadmin/DAM/env/documents/2012/EB/ECE_EB_AIR_2012_18_R.pdf (22.10.2016) (in Russian).

4. Volkova M.V., Ulanova T.S. Melkodispersnye chasticy PM2,5 i PM10 v vybrosah avtotransporta [The fine particles PM2,5 and PM10 in road transport emissions]. Modernizacija i nauchnye issledovanija v transportnoj komplekse: materialy mezhdunarodnoj nauchno-prakticheskoj konferencii [Upgrade and scientific researches in transport sector: materials of the international scientific-practical conference]. Perm', April 14-15, 2016, pp. 157-159 (in Russian).

5. Volkova M.V., Ulanova T.S. Melkodispersnye chasticy PM2.5 i PM10 v vozduhe na urbanizirovannyh territorijah [The fine particles PM2,5 and PM10 in air of the urbunized areas]. Jekologija i nauchno-tehnicheskij progress. Urbanistika: materialy Vserossijskoj nauchno-prakticheskoj konferencii studentov, aspirantov i molodyh uchenyh (s mezhdunarodnym uchastiem) [Environment and scientific and technical progress. Urban: Materials of All-Russian scientific-practical conference of 
students, graduate students and young scientists (with international participation) ]. Perm', November 20, 2015, pp. 71-74 (in Russian).

6. Gileva O.V., Volkova M.V. Instrumental'nye issledovanija melkodispersnyh chastic $\mathrm{v}$ atmosfernom vozduhe [Instrumental investigationsof the fine particles in the air]. Fundamental'nye i prikladnye aspekty analiza riska zdorov'ju naselenija: materialy Vserossijskoj nauchno-prakticheskoj internet-konferencii molodyh uchenyh i specialistov Rospotrebnadzora [Materials of the all-Russian scientific and practical conference of young scientists and Rospotrebnadzor specialists "Fundamental and applied aspects of population health risk"]. Perm', October 5-9, 2015, pp. 213-216 (in Russian).

7. GN 2.1.6.2604-10. Dopolnenie № 8 k GN 2.1.6.1338-03. Predel'no dopustimye koncentracii (PDK) zagrjaznjajushhih veshhestv $\mathrm{v}$ atmosfernom vozduhe naselennyh mest [GN 2.1.6.2604-10. Addition № 8 to the GN 2.1.6.1338-03. Maximum permissible concentration (MPC) of the pollutants in the ambient air of populated areas]. Utv. postanovleniem Glavnogo gosudarstvennogo sanitarnogo vracha RF ot 19.04.2010 g. № 26 [Approved by by the Resolution of the Chief State Sanitary Doctor of the Russian Federation from 19.04.2010, No.]. Available at: http: //docs.cntd.ru/document/902216601 (18.10.2016) (in Russian).

8. Drozd V.A., Kiku P.F., Anan'ev V.Ju. [et al]. Godovye kolebanija chastic PM10 v vozduhe Vladivostoka [Annual fluctuations of PM10 particles content in the air of Vladivostok]. Izvestija Samarskogo nauchnogo centra Rossijskoj akademii nauk, 2015, vol. 17, no. 5 (2), pp. 646-651 (in Russian).

9. Golohvast K.S. Nano- i mikrorazmernye chasticy atmosfernyh vzvesej i ih jekologicheskij jeffekt (na primere gorodov juga dal'nego vostoka): diss. ... d-ra biol. Nauk [Nano- and micro-sized particles of atmospheric mists and their environmental impact (for example, cities in the south of the Far East): Diss. ... Dr. biol. sciences]. Vladivostok, 2014, 310 p. (in Russian).

10. Golohvast K.S., Kiku P.F., Hristoforova N.K. Atmosfernye vzvesi i jekologija cheloveka [Atmospheric suspensions and human ecology]. Jekologija cheloveka, 2012, no. 10, pp. 5-10 (in Russian).

11. Golohvast K.S., Chernyshev V.V., Ugaj S.M. Vybrosy avtotransporta i jekologija cheloveka (obzor literatury) [Car Exhausts And Human Ecology (Literature review) ]. Jekologija cheloveka, 2016, no. 1, pp. 914 (in Russian).

12. GOST 17.2.3.01-86. Ohrana prirody. Atmosfera. Pravila kontrolja kachestva vozduha naselennyh punktov [GOST 17.2.3.01-86. Protection of Nature. Atmosphere. Air quality control instructions in human settlements]. Available at: http: //www.ekan.ru/sites/docs/GOST-17-2-3-01-86.pdf (18.11.2016) (in Russian).

13. Direktiva N 2008/50/ES Evropejskogo Parlamenta i Soveta o kachestve atmosfernogo vozduha i merah ego ochistki. Evropejskij sojuz. Strasburg, 21 may 2008. [Directive No. 2008/50/EC of the European Parliament and of the Council on Ambient air quality and cleaner air for Europe. Strasbourg, 2008] (in Russian).

14. Borovlev A.Je., Kungurcev S.A., Migal' L.V., Solov'ev V.I. Zagrjaznenie atmosfernogo vozduha goroda Belgoroda chasticami pyli malyh razmerov [Air pollution by dust particles of small size of the city of Belgorod]. Uchenye zapiski: jelektronnyj nauchnyj zhurnal Kurskogo gosudarstvennogo universiteta, 2013, no. 1 (25), pp. 269-272. Available at: http: //scientific-notes.ru/pdf/029-039.pdf (18.10.2016) (in Russian).

15. Lezhnin V.L., Kon'shina L.G., Sergeeva M.V. Ocenka riska dlja zdorov'ja detskogo naselenija, obuslovlennogo zagrjazneniem atmosfernogo vozduha vybrosami avtotransporta, na primere g. Saleharda [Assessment of children's health risk posed by traffic-related air pollution as exemplified by the city of Salekhard]. Gigiena i sanitarija, 2014, no. 1, pp. 83-86 (in Russian).

16. Ob utverzhdenii Metodicheskih rekomendacij po obespecheniju kachestva izmerenij koncentracij vzveshennyh chastic (RM2,5 i RM10) v atmosfernom vozduhe Sankt-Peterburga: rasporjazhenie Komiteta po prirodopol'zovaniju, ohrane okruzhajushhej sredy i obespecheniju jekologicheskoj bezopasnosti Sankt-Peterburga ot 20.05.2010 N 75-R [On Approval of the recommendations on quality assurance of measurements of concentrations of suspended particles (PM2.5 and RM10) in the atmosphere of St. Petersburg: the disposal of the Committee for Nature Use, Environmental Protection and Ecological Safety of St. Petersburg dated 20.05.2010 N 75-P]. Available at: http: //docs.cntd.ru/document/891832021 (15.11.2016) (in Russian). 
17. Oficial'nyj sajt gosudarstvennogo prirodoohrannogo bjudzhetnogo uchrezhdenija «Mosjekomonitoring» [The official website of the state environmental budget entity "Mosekomonitoring]. Available at: http: //www.mosecom.ru (15.10.2016) (in Russian).

18. Pshenin V.N. Zagrjaznenie vozduha melkodispersnymi chasticami okolo avtomobil'nyh dorog [Air pollution by fine particles near highways]. Modernizacija i nauchnye issledovanija v dorozhnoj otrasli: sbornik nauchnyh trudov, 2013, pp. 96-104 (in Russian).

19. RD 52.04.186-89. Rukovodstvo po kontrolju zagrjaznenija atmosfery [RD 52.04.186-89. Guide for the air pollution control]. utv. Goskomgidrometom SSSR 01.06.1989, Glavnym gosudarstvennym sanitarnym vrachom SSSR 16.05.1989. [approved by the USSR State Committee 01.06.1989, the Chief State Sanitary Doctor of the USSR 16.05.1989]. Moscow, 1991, 641 p. Available at: http: //ohranatruda.ru/ot_biblio//normativ/data_normativ/44/44486/index.php (20.10.2016) (in Russian).

20. RD 52.04.840-2015. Primenenie rezul'tatov monitoringa kachestva atmosfernogo vozduha, poluchennyh s pomoshh'ju metodov nepreryvnyh izmerenij [RD 52.04.840-2015. Application of the results of air quality monitoring, obtained by continuous measurement methods]. Utv. Rosgidrometom 29.12.2015. Available at: http: //docs.cntd.ru/document/1200133380 (15.11.2016) (in Russian).

21. Rukovodstvo po jekspluatacii pylemera DustTrak DRX modeli 8533/8534 [Operating Instructions for dust meter DustTrak DRX model 8533/8534]. Saint Petersburg, 2009 (in Russian).

22. Ulanova T.S., Gileva O.V., Volkova M.V. Opredelenie chastic mikro- i nanodiapazona v vozduhe rabochey zony na predpriyatiyah gornodobyvayushhey promyshlennosti [Determination of micro and nanoparticles in the workplace area at the enterprises of mining industry]. Analiz riska zdorovyu, 2015, 4, pp. 44-49 (in Russian).

23. Cheng M., Chui H., Yang C. The effect of coarse particles on daily mortality: a case -crossover study in a subtropical city, Taipei, Taiwan. International Journal of Environmental Research and Public Health, 2016, no. 13, 347 p. DOI: 10.3390/ijerph13030347.

24. Environmental Protection Agency. National Ambient Air Quality Standards for Particulate Matter; Final rule. Federal Register, 2006, vol. 71, 94 p. Available at: https: //www3.epa.gov/ttnamti1/files/ambient/pm25/ pt535806.pdf (18.10.2016).

25. WHO Air quality guidelines for particulate matter, ozone, nitrogen, dioxide and sulfur dioxide Global update 2005. Summary of risk assessment. (WHO/SDE/PHE/OEH/06.02). World Health Organization, 2006, 22 p. Available http: //apps.who.int/iris/bitstream/10665/69477/1/WHO_SDE_PHE_OEH_06.02_eng.pdf (22.10.2016).

26. Kan H., London S. J., Chen G. et al. Differentiating the effects of fine and coarse particles on daily mortality in Shanghai, China. Environment International, 2007, no. 33, pp. 376-384.

Ulanova T.S., Antipieva M.V., Volkova M.V., Gileva M.I. Investigations of fine particles concentrations in the atmospheric air near highways. Health Risk Analysis, 2016, no. 4, pp. 34-40. DOI: 10.21668/health.risk/2016.4.05.eng

Received: 27.09.2016

Accepted: 19.12 .2016

Published: 30.12 .2016 